\title{
PPS and EU Regional Price Level Problem
}

\author{
Jan Cadil $^{1,2, *}$ and Petr Mazouch ${ }^{1}$ \\ ${ }^{1}$ University of Economics, Prague; ${ }^{2}$ Unicorn College, Czech Republic
}

\begin{abstract}
The Purchasing Power Standard (PPS) is widely used for economic analyses, studies and strategic documents in the European Union. Although it is a necessity to take the purchasing power i.e. price level into consideration the state of art of PPS is not usable at regional level. The current PPS is not reflecting regional prices but is based on one country price level. This might lead to serious imperfections and misspecifications especially in relation to regionally oriented policies like the Cohesion Policy. Using PPS for analyzing convergence reveals quite puzzling conclusions which are supporting this possible problem of PPS. It is vital for the EU policies to become efficient to compute new regional price levels or to substantially modify current PPS.
\end{abstract}

Keywords: Purchasing power standard (PPS), regional price level, convergence, JEL: C18, E31, P48.

\section{INTRODUCTION}

Contemporary economic analyses very often deal with variables set in Purchasing Power Parities (PPP) or Purchasing Power Standard (PPS) ${ }^{1}$. It is necessary (without any doubt) to involve purchasing power of a country or a region into consideration because neglecting it would lead to serious misleading and misspecifications of related theories and models. However this must be undertaken with care especially on regional levels. In spite of large variety of important economic indicators let us for now focus on GDP per capita as most likely the main and most important statistic indicator of a country's or region's economic performance and development. In spite of many imperfections (for example it does not include the quality of life) it is still an indicator with probably the highest influence on economic and regional policy and strategy shaping at all levels regional, national and supra-national. These policies and strategies are usually backed by economic (usually comparative) analyses and studies which often use GDP per capita in PPP or PPS. It is true that some analyses in history were based solely on exchange rate conversions of GDP, however as Methodological manual on purchasing power parities (European Communities/OECD, 2006) shows such a method is inappropriate and yields significantly distorted results. The main reason is that pure exchange rate conversion of GDP does not include national price levels and therefore virtually increases GDP in countries with higher price levels and on the other hand decreases GDP in countries with relatively lower price levels ${ }^{2}$. Therefore

*Address correspondence to this author at the Unicorn College, Czech Republic; Tel: +420 224095 621;

E-mails: jan.cadil@unicorncollege.cz; jan_cadil@yahoo.com

${ }^{1}$ PPS is an artificial unit derived from PPP and exchange rate. In practice indicators in PPS are computed as dividing the nominal value in domestic currency by PPP (see European Comparison Programme 2007).

${ }^{2}$ It is true that according to the PPP theory the exchange rate should reflect the price levels rates. Nevertheless is is not true as not all goods and services are "trade-able" among the countries.
EUROSTAT and OECD are now recommending performing all comparative analyses on PPP or PPS bases respectively. The purchasing power parity (or standard) should ensure the comparability of GDP (or any other indicator) with respect to individual (national or regional) price levels. As will be explained later in this note, unfortunately not even this method yields good results at regional levels as it suppresses regional price levels. The analyses and studies mentioned above are mainly focused on three dominant areas. In the first area there are numerous simple comparative analyses focusing on regional economic performance comparisons. Secondly there is a large and popular convergence area covering all real and nominal convergence studies and thirdly there are highly demanded analyses focused on economic and regional policy assessment. In all these analytical applications authors almost always use GDP in PPS utilizing EUROSTAT methodology and database. Table 1 exhibits some examples of PPP or PPS utilization at regional level.

The PPS is however not only economic but eventually an important political issue. The inaccurate data about the economic level of the regions may generally lead the policy makers to make wrong decisions. This affects not only regional policies but also political debates and even the election campaigns ${ }^{3}$. Out of actual political applications that are based on PPS conception there is a typical example of EU cohesion policy. Cohesion policy generally supports regions in need when the objective 1 - Convergence covers $81,5 \%$ of all EU cohesion funding. However this most important and financially extensive objective helps only those regions which have the GDP/capita in below $75 \%$ of EU average. This GDP is again measured in PPS. This is quite serious because as will be explained later PPS does not reflect regional price levels. Therefore EU could support regions which are in fact not lagging behind but have

${ }^{3}$ For example the long time governing party (ODS) based its election campaign in Prague in 2010 on the "fact" that Prague is the 5th most wealthy region in EU 27. Hardly any Prague citizen believed he is wealthier than citizen of Vienna and ODS lost its majority (there were other factors in play of course). Nevertheless according to the Eurostat data Prague really is at the fifth position in GDP/capita in PPS. 
Table 1. Analyses Using PPP/PPS at EU Regional Level (Examples)

\begin{tabular}{|c|c|c|}
\hline Regional Economic Comparison & Convergence and Growth & Regional Policy Assessment \\
\hline \hline $\begin{array}{c}\text { Fagerberg, Guerrieri, Verspagen (1999). } \\
\text { The economic challenge for Europe: adapting to } \\
\text { innovation based growth }\end{array}$ & $\begin{array}{c}\text { López-Bazo, Vayá, Mora, Surinach(1999). } \\
\text { Regional economic dynamics and convergence in } \\
\text { the European Union }\end{array}$ & $\begin{array}{c}\text { Button, Pentecost (1999). Regional Economic } \\
\text { Performance within the European Union }\end{array}$ \\
$\begin{array}{c}\text { Button, Pentecost (1999). Regional Economic } \\
\text { Performance within the European Union }\end{array}$ & $\begin{array}{c}\text { Le Pen (2011). A pair-wise approach to output } \\
\text { convergence between European regions }\end{array}$ & $\begin{array}{c}\text { Terribile (2010). Measuring the Impact of the } \\
\text { European Regional Policy on Economic Growth: } \\
\text { a Regression Discontinuity Design Approach }\end{array}$ \\
\hline $\begin{array}{c}\text { Dunford, M. and Smith, A. (2000). Catching Up } \\
\text { or Falling Behind? Economic Performance and } \\
\text { Regional Trajectories in the "New Europe". }\end{array}$ & $\begin{array}{c}\text { Barro, Sala-I-Martin (1991). Convergence } \\
\text { Across States and Regions. }\end{array}$ & $\begin{array}{c}\text { Wishlade,Yuill (1997). Measuring Disparities for } \\
\text { Area Designation Purposes Issues for the } \\
\text { European Union }\end{array}$ \\
\hline $\begin{array}{c}\text { Gardiner, Martin, Tyler (2004). Competitiveness, } \\
\text { Productivity and Economic Growth across the } \\
\text { European Regions }\end{array}$ & $\begin{array}{c}\text { Brasili, Gutierrez (2004). Regional Convergence } \\
\text { across European Union }\end{array}$ & $\begin{array}{c}\text { Bachtler, Wishlade (2004). Searching for } \\
\text { Consensus: The Debate on reforming EU } \\
\text { Cohesion Policy }\end{array}$ \\
\hline $\begin{array}{c}\text { Ciurea (2010). Economic Disparities between EU } \\
\text { Sates and Regions }\end{array}$ & $\begin{array}{c}\text { Meliciani V., Perachi (2004). Convergence in } \\
\text { Per-capita GDP Across European Regions: } \\
\text { A Reappraisal }\end{array}$ & $\begin{array}{c}\text { Cappelen, Castellacci, Fagerberg, Verspagen } \\
\text { (2003). The Impact of EU Regional Support on } \\
\text { Growth and Convergence in the European Union }\end{array}$ \\
\hline
\end{tabular}

relatively lower price levels. Generally using PPS at regional level can lead to distorted results, policy misspecifications and allocation inefficiency of cohesion funds.

\section{PPS AT REGIONAL LEVEL - EU STATISTICAL PROBLEM}

At present time there is no complex database which would offer regional price levels of member states regions of European Union (at NUTS 2 or NUTS 3 level). National statistical offices focus mainly on national price level development using standard methodology and tools (CPI, PPI, GDP deflator). For international comparisons they offer regional GDP in PPS; however the parity is derived not from the regional prices but from average national prices. The same methodology is, by the way, used by EUROSTAT for all member states. The result of this methodological approach is data which does not reflect the real economic situation of regions (at national and supranational levels) and consequently distorts analyses and negatively affects related policies. Comparative analysis dealing with regions are therefore using either nominal values leading to distorted results (see footnote 3 ) or PPS, which is however also wrong as explained above. Nevertheless such analyses and studies are main economic inputs for regional policy conception and strategies and GDP in PPS is a vital indicator for EU funding. For example in accordance with this methodological approach we may see Prague having a GDP per capita in PPS at $215 \%$ of Czech Republic average and approximately at $172 \%$ of EU 27 average 4 . Taking the much higher price level in Prague in comparison to other regions and Czech Republic average into account it is more than likely that Prague is strongly overvalued in nominal terms and in PPS as well.

${ }^{4}$ This was the situation in 2007 when we (EUROSTAT) have the latest data. These data are often commented and presented in media. For instance in February 2010 Czech newspapers E15 published a survey based on EUROSTAT data announcing Prague as the fifth wealthiest region in EU 27. Again they used GDP per capita in PPS.
Regarding the price level computation methodology itself there is standard methodology of GDP in PPP (PPS) computation utilized by EUROSTAT now. This methodology is based on EKS (Éltetö-Köves-Szulc) method which requires data concerning the volume of consumed goods and services in particular countries (regions) and concludes in identification of representative groups of goods and services. Despite the reliability of this method which could easily be used at a national level it is often not possible to use it for price level calculation at regional levels - usually because of lack of data. It is necessary to modify the methodology for regional price level computation purposes according to data availability in particular member states (there is a problem of regional consumption basket data gathering and scope of regional prices observed).

Despite the necessity and urgency of accurate regional price statistics demonstrated above no deeper research has been undertaken in this field yet as far as we know either on national or international grounds. EUROSTAT was considering computation of regional price levels and re-computation of regional GDP in PPS several years ago but they abandoned this cause. We believe that reaching proper price levels could solve many puzzles that are hunting researchers and politicians around Europe. For the cohesion policy mentioned above setting proper price levels would ensure that cohesion policy is really helping those regions that are in need and not the regions that are "in need" just because of applied methodology and relatively lower price levels.

\section{CONVERGENCE AND DIVERGENCE AT NATIONAL AND REGIONAL LEVEL (EU)}

As mentioned above PPS possibly causes many analytical and political caveats because it does not reflect the real regional price levels. To make a sort of proof we focus on the convergence theory. Presuming EU member states national prices i.e. GDP in PPS properly set convergence theory should work and poorer countries should grow faster 
than the rich ones ${ }^{5}$. On the other hand taking regions into account - among and within the countries - where the prices are set improperly we probably will not witness convergence even if there is one ${ }^{6}$. For the convergence analysis we take GDP per capita in PPS in 1996 (in logarithms) and GDP per capita in PPS yearly average growth in period 1996-2009 . Fig. (1) shows the convergence among the EU countries while Fig. (2) exhibits convergence among the EU regions at NUTS 2 level, Fig. (3) at NUTS 3 level $^{8}$.

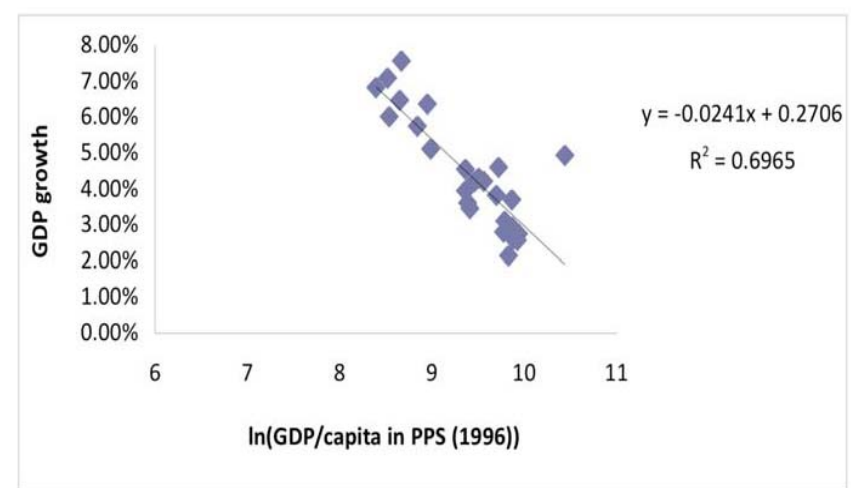

Source: Eurostat, own elaboration

Fig. (1). EU countries convergence.

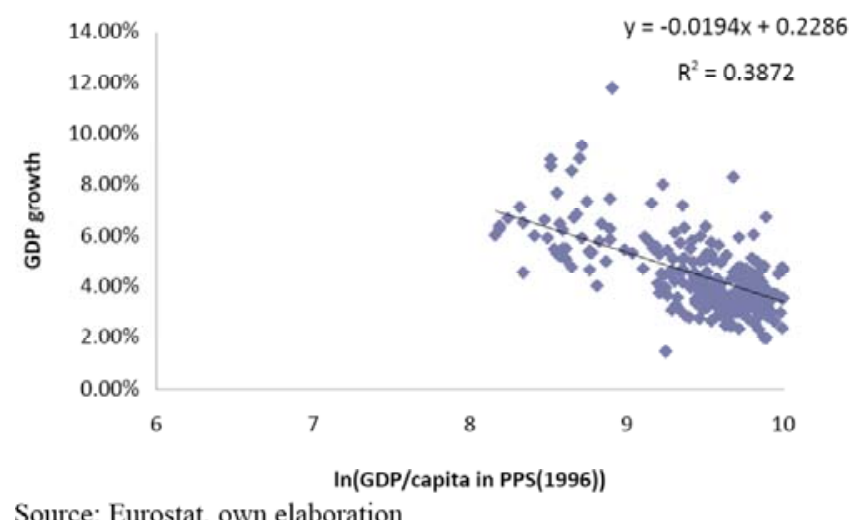

Fig. (2). EU regions (NUTS 2) convergence.

Figs. (1-3) show that there is a convergence among the EU countries and regions but the convergence strength decreases as we use smaller regional units. In other words as we move further from the country average PPS the convergence is getting weaker. We could presume that within the countries regional convergence should work better than among the countries because of similar inner (institutional) conditions. Table 2 exhibits a development in coefficient of variance which can be used for analyzing the differences within the countries. Generally decrease in variation coefficient means convergence tendency among the

${ }^{5}$ We test the famous beta convergence theory coming from Solow (1956). We treat whole EU as a convergence club with similar economic structure.

${ }^{6}$ Of course the cause might be ,traditional" one that regions are differing substantially in their structure in comparison to countries and therefore we witness non-convergence. Although this might be true we should not give up the PPS misspecification theory.

${ }^{7}$ We use a geometric mean of yearly growth rates 1997-2009. Simple cross-country OLS method is used which is a convenient basic approach to analyze the convergence problem. See Barro, Sala-i-Martin (1995) for example.

${ }^{8}$ Without Denmark and two UK regions where the data is not available for requested time period. 270 NUTS 2 and 1190 NUTS 3 regions were included. regions within the country increase in coefficient indicates divergence. NUTS 3 regions were used for the purpose of variation coefficient computation.

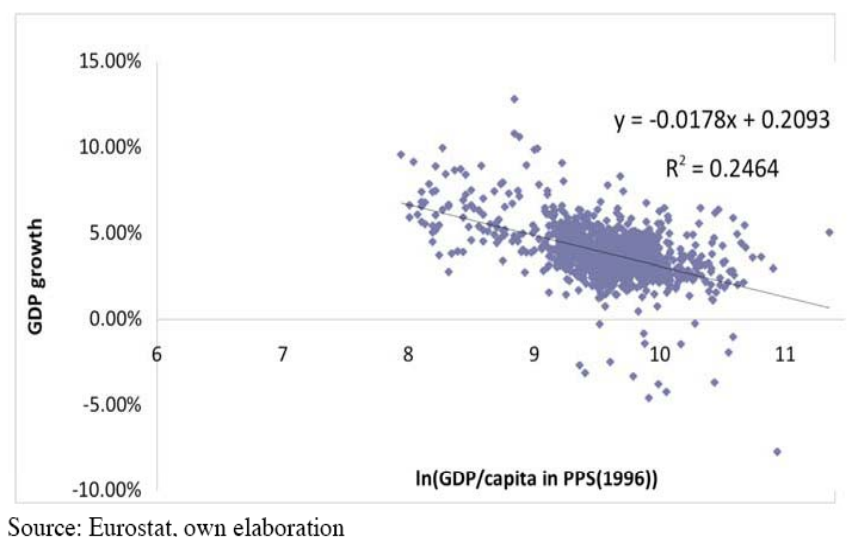

Fig. (3). EU regions (NUTS 3) convergence.

Quite surprisingly we see that in most EU countries there are divergence and not convergence tendencies. Moreover there is no visible pattern in this development. Some EU 15 member states are diverging (France, United Kingdom etc.) some are converging, although the convergence is usually very slight ${ }^{9}$. The same is true for accession countries Poland is converging while Czech Republic or Bulgaria are diverging. Even the size of the country does not matter and probably not even the geographical location. We cannot find any "convergence clubs" regarding within the countries convergence. Again one explanation of this puzzle could lie in PPS and regional price levels misspecification.

\section{CONCLUSIONS AND FURTHER RESEARCH OPPORTUNITIES}

Purchasing power standard (PPS) is widely used in contemporary economic research and following policies and strategies at regional, national and supra-national level of European Union member states. We find various studies and research papers utilizing the PPS at the regional level with substantial impact on regional policies and policy maker's decisions and proclamations. The thematic scope covers various issues from migration to economic growth and social cohesion. Although it is necessary to make any relevant analysis and subsequent political decision with respect to regional price levels, the PPS serves well only at national level and is probably unsuitable for regional purposes. Present PPS methodology used by Eurostat or OECD does not really reflect regional prices. It is using sort of average national price level instead. This is resulting in possible imperfections while some regions are artificially overestimated in various indicators (like GDP/capita) while others are artificially underestimated. Such approach inevitably leads to political bias with possibly serious long term impacts on the regions. The most important political impact of this misspecification at EU supra-national level is probably possible inefficiency in allocation of funds via Cohesion Policy. It is possible that regions that are artificially

${ }^{9}$ With one surprising exception which is Greece. 
Table 2. Within the Countries Convergence (Nuts 3 Level)

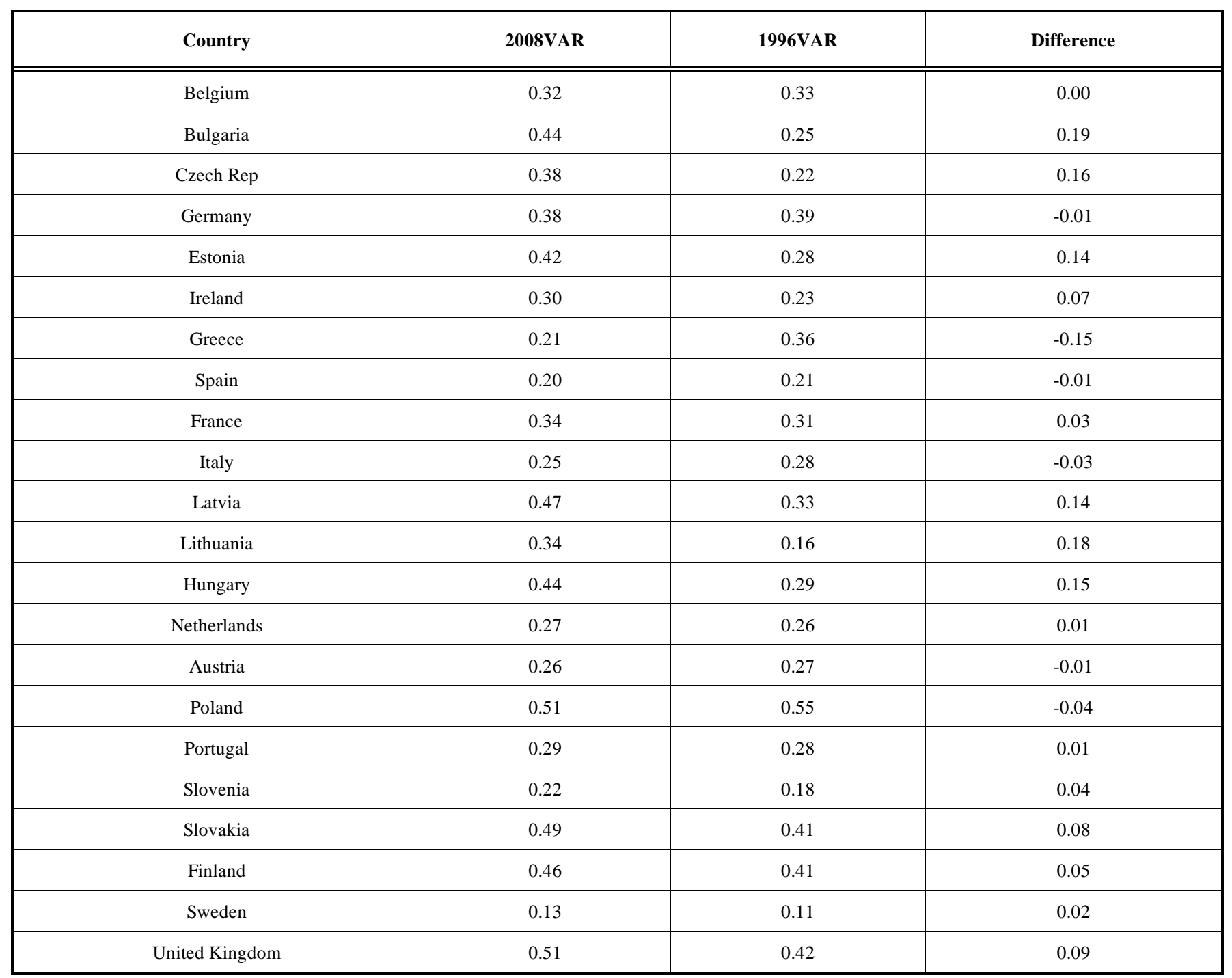

Source: Eurostat, own elaboration.

underestimated reach the allocation criteria (which is less than $75 \%$ of EU average in GDP/capita indicator measured in PPS) while artificially overestimated regions do not. Eventually a political consensus to support lagging regions and promote convergence may turn out to an inefficient system which leads to regional divergence. To prove that there is such possibility of wrong regional price levels setting we have shown that convergence among the EU countries among the EU regions and within the countries differs substantially. The smaller regions we take the weaker convergence occurs. Moreover on the within the country level we witness mostly divergence. Although this looks like a puzzle and a feeding ground for some new convergence theories and models we believe that one possible explanation could be right in the PPS. Therefore it is necessary to focus on proper regional price levels computation in the future and make further research in this field. Although it is not a political but a statistical issue it has important political consequences and it is in our opinion even a political challenge to change the current methodology.

\section{ACKNOWLEDGEMENT}

This paper is written under the support of the University of Economics, Prague, No IGA 12/2011.

\section{CONFLICT OF INTEREST}

None.

\section{REFERENCES}

Bachtler, J., \& Wishlade, F. (2004). European Policies Research Centre, University of Strathclyde 2004. Searching for Consensus: The Debate on reforming EU Cohesion Policy. European Policies Research. Paper no. 55 .

Barro J. R., \& Sala-I-Martin, X. (1991). Convergence Across States and Regions. Brookings Papers on Economic Activity, 107-182.

Barro, R. J., \& Sala-i-Martin, X. (1995). Economic Growth. McGraw-Hill. Brasili, C., \& Gutierrez, L. (2004). Regional Convergence across European Union. Development and Comp Systems 0402002, Economics Working Paper Archive EconWPA.

Busillo, F., Muccigrosso, T., Pellegrini, G., Tarola, O., \& Terribile, F. (2010). Measuring the impact of the european regional policy on economic growth: a regression discontinuity design approach. working papers from Sapienza University of Rome 6/10,DTE. 
Button, K., \& Pentecost, E. (1999). Regional Economic Performance within the European Union. Edward Elgar Publishing.

Cappelen, A., Castellacci, F., Fagerberg, J., \& Verspagen, B. (2003). The Impact of EU Regional Support on Growth and Convergence in the European Union. Journal of Common Market Studies, 41, 621-644.

Ciurea, I. (2010). Economic Disparities between EU Sates and Regions. Scientific Bulletin - Economic Sciences, 9, 39-50.

Dunford, M., \& Smith, A. (2000). Catching Up or Falling Behind? Economic Performance and Regional Trajectories in the "New Europe". Economic Geography, 76, 69-195.

European Communities/OECD (2006). EUROSTAT-OECD Methodological manual on purchasing power parities. Office for Official Publications of the European Communities.

Fagerberg, J., Guerrieri, P., \& Verspagen, B., ed. (1999). The Economic challenge for Europe: Adapting to Innovation based Growth. Edward Elgar Publishing.
Gardiner, B., Martin, R., \& Tyler, P. (2004). Competitiveness, Productivity and Economic Growth across the European Regions. Regional Studies, 38, 1045-1067.

Le Pen,Y. (2011). A pair-wise approach to output convergence between European regions. Economic Modelling, 28/3, 955-964.

López-Bazo, E., Vayá, E., Mora, A.J, \& Suriñach, J. (1999). Regional economic dynamics and convergence in the European Union. Annals of Regional Science, 33, 343-370.

Meliciani, V., \& Peracchi, F. (2004). Convergence in Per-capita GDP Across European Regions: A Reappraisal. CEIS Research Paper 58, Tor Vergata University, CEIS.

The Council of the European Union (2006). Concil Regulation (EC) No 1083/2006. Official Journal of the European Union, 210/25-210/77.

Wishlade, F., \& Yuill, D. (1997). Measuring Disparities for Area Designation Purposes Issues for the European Union. Regional and Industrial Policy Research Paper no. 24. European Policies Research Centre, University of Strathclyde. Available at: www.eurostat.home.

(c) Cadil and Mazouch.; Licensee Bentham Open.

This is an open access article licensed under the terms of the Creative Commons Attribution Non-Commercial License (http://creativecommons.org/licenses/by-nc/3.0/) which permits unrestricted, non-commercial use, distribution and reproduction in any medium, provided the work is properly cited. 